Original article

\title{
Modes of worker reproduction, reproductive dominance and brood cell construction in queenless honeybee (Apis mellifera L.) colonies
}

\author{
Peter NeumanN ${ }^{a}$, b*, H. Randall HePBuRN ${ }^{a}$, Sarah E. RAdLOFF ${ }^{\mathrm{c}}$ \\ ${ }^{a}$ Department of Zoology and Entomology, Rhodes University, Grahamstown 6140, South Africa \\ b Martin-Luther-Universität Halle-Wittenberg, Fachgebiet Molekulare Ökologie, \\ Institut für Zoologie, Kröllwitzerstr. 44, 06099 Halle/Saale, Germany \\ ${ }^{c}$ Department of Statistics, Rhodes University, Grahamstown 6140, South Africa
}

(Received 14 October 1999; revised 18 February 2000; accepted 21 February 2000)

\begin{abstract}
Colonies of A. m. capensis, A. m. scutellata and their natural hybrids were dequeened and debrooded. The ratio of worker/drone cell construction and the sex of laying worker offspring were determined for 26 colonies. All A. m. capensis laying workers were thelytokous and all A. m. scutellata arrhenotokous. $42.1 \%$ of the hybrid colonies produced only female offspring while none produced only male offspring. This shows a significant advantage for thelytokous laying workers to become reproductively dominant in hybrid colonies. A. $m$. capensis colonies built only worker cells and A. $m$. scutellata only drone cells. Hybrid colonies produced either both cell types or only worker cells according to the mode of laying worker reproduction. In all colonies where laying workers produced male offspring drone cell building was found. Our data strongly indicates that the mode of worker reproduction holds important consequences for cell construction and reproductive dominance.
\end{abstract}

Apis mellifera capensis / Apis mellifera scutellata / honeybee / hybrids / laying worker / reproductive dominance / brood cell

\section{INTRODUCTION}

It has recently been shown that the mode of worker reproduction holds important consequences for the behaviour of honeybees. Indeed, thelytoky has significant effects on absconding behaviour of colonies [7], as well as on drifting [unpublished data] and policing behaviour of workers [13]. Two behaviours of honeybee workers which occur after queen loss are highly important for the reproductive capacity of these

* Correspondence and reprints

E-mail: p.neumann@ @ru.ac.za 
orphaned colonies (especially in recently absconded colonies): the reproductive dominance hierarchies among laying workers and the construction of brood cells.

Colony performance in queenless honeybees depends on the proportion of subordinate and dominant workers [8]. Because honeybee queens mate with many males [15] the colony consists of a large number of different patrilines among which there is reproductive competition under queenless conditions [12]. After a few weeks offspring of only some dominant patrilines are reared to the adult stage. If colonies simultaneously consist of patrilines capable of both thelytokous and arrhenotokous parthenogenesis (as is the case in the natural hybrid zone between A. m. capensis and A. m. scutellata), which patrilines become reproductively dominant after queen loss, and what are the consequences?

If the mode of worker reproduction exclusively determines reproductive dominance among workers, we would expect naturally occurring hybrid colonies between A. $m$. capensis and A. m. scutellata consisting of both arrhenotokous and thelytokous patrilines to produce either adult worker or drone offspring but not both. If, however, the mode of worker reproduction has only a modest impact on reproductive dominance hierarchies, we would expect successful reproduction of both arrhenotokous and thelytokous patrilines in queenless hybrid colonies.

In this paper we address the question: does the mode of worker reproduction have an impact on reproductive dominance and on brood cell construction in queenless honeybee colonies in the natural hybrid zone between $A$. $m$. capensis with thelytokous laying workers and $A$. m. scutellata with arrhenotokous laying workers?

\section{MATERIALS AND METHODS}

To assess the cell building pattern and subsequent production of laying worker offspring the following procedures were adopted. Ten queenright colonies were selected at each of seven localities along a transect extending from the natural distribution area of $A$. m. capensis, through the hybrid zone of capensis-scutellata which naturally occurs between them in the Eastern Cape area of South Africa, finally to the region of $A$. $m$. scutellata (Tab. I). Localities were chosen to include pure $A$. $m$. capensis (Port Elizabeth [33.58S, 25.36E]), hybrids which are predominantly $A$. $m$. capensis, according to morphological analysis [4] (Addo [33.29S, 25.46E], Fort Beaufort [32.48S, 26.38E], Stutterheim [32.33S, 22.28E]) or predominantly A. m. scutellata (Queenstown [31.32S, 7.00E] and Molteno [31.22S, 26.22E]) and pure A. m. scutellata (Pretoria [25.46S, 28.12E]).

All of the experimental colonies were dequeened and completely stripped of any nesting material including brood, stores and combs. The remaining workers were then given only empty frames (without any wax foundation). Manipulations were done in situ in the different apiaries to preclude intersubspecific drifting, dispersing, introgression or amalgamation of the different populations $[3,7,16]$. This is highly important because $A$. m. capensis workers can invade other colonies and successfully reproduce (cf. [4]). Also, it must be noted that these bees are native honeybees in this region where there is no transport or migration of colonies nor is any bee breeding practised. Thus, the colonies studied are authentic samples of the natural wild population.

After 30 days the various localities were revisited and the full contents of all hives were collected and brought to our laboratory for the analysis of laying worker progeny and comb building behaviour. Thus, the ratios of worker cell to drone cell building were determined regardless of whether they contained any offspring or not and the progeny of laying workers was sexed. The occurrence of queen cell construction was also recorded. 
Table I. Construction of brood cells and sex of laying worker offspring in queenless colonies of A. m. capensis, A. m. scutellata and their natural hybrids. The total number of constructed queen cells per location are given ( $\mathrm{N}=$ sample size of remaining colonies used for data analysis). Part of the numerical data was taken from another study [6] but has not previously been considered in terms of reproductive fitness.

\begin{tabular}{|c|c|c|c|c|c|c|}
\hline Group & & Locality & $\mathbf{N}$ & $\begin{array}{l}\text { Worker/drone } \\
\text { cell ratio }\end{array}$ & $\begin{array}{c}\text { Sex of } \\
\text { offspring }\end{array}$ & $\begin{array}{l}\text { Queen } \\
\text { cells }\end{array}$ \\
\hline capensis & & Port Elizabeth & 9 & $1: 0$ & female & 81 \\
\hline \multirow[t]{11}{*}{ hybrids } & \multirow{8}{*}{$\begin{array}{l}\text { predominantly } \\
\text { capensis }\end{array}$} & Addo & 1 & $1: 0$ & female & 12 \\
\hline & & & 1 & $2: 1$ & female/male & 13 \\
\hline & & & 1 & $4: 1$ & female/male & 8 \\
\hline & & Fort Beaufort & 1 & $1: 1$ & female/male & 5 \\
\hline & & & 1 & $2: 1$ & female/male & 5 \\
\hline & & & 1 & $20: 1$ & female/male & 5 \\
\hline & & Stutterheim & 2 & $2: 1$ & female/male & 4 \\
\hline & & & 1 & $1: 0$ & female & 1 \\
\hline & \multirow{3}{*}{$\begin{array}{l}\text { predominantly } \\
\text { scutellata }\end{array}$} & Queenstown & 2 & 1:0 & female & 20 \\
\hline & & Molteno & 2 & $1: 0$ & female & 2 \\
\hline & & & 1 & $10: 1$ & female/male & 1 \\
\hline \multicolumn{2}{|l|}{ scutellata } & Pretoria & 3 & $0: 1$ & male & 0 \\
\hline \multicolumn{2}{|l|}{ Total } & & 26 & & & \\
\hline
\end{tabular}

It must be understood that the amount of new comb construction varied quite considerably among colonies ranging from about 0.5 of a Langstroth brood frame up to five frames of new comb. Naturally, the amount of brood produced also varied in a similar way from just a couple of dozens to several hundreds. Nonetheless all brood was sexed in all combs in the pharate adult stage (pre-hatching imagos) and all cells were assigned to either drone or worker type and expressed in ratio form. Clearly, some colonies contained more comb and brood than others, but despite the relative abundance or paucity of both comb and brood among the different colonies, each individual colony represents an independent sample.

We used $\chi^{2}$ - and z-tests to test for the distribution of arrhenotokous and thelytokous reproducing workers and for the distri- bution of comb cell building among the hybrid colonies. To test the relationship between the taxa and the amount of queen cell construction we calculated a correlation across the transect.

\section{RESULTS}

As is often the case under experimental perturbations of this magnitude [7], 43 of our original 70 test colonies absconded (10\% of $A$. m. capensis, $72 \%$ of the hybrids and $70 \%$ of A. m. scutellata) and one colony died, leaving a data base of 26 colonies (Tab. I). Clearly, we do not know the actual fates of the absconded colonies. However, there is no statistical bias in the final results because analysis was restricted to these colonies that remained in the apiaries.

The sexes of offspring produced by queenless laying worker colonies of 
A. m. capensis, A. m. scutellata and their natural occurring hybrids are shown in Table I. Pure A. m. capensis colonies produced only female offspring whereas the pure A. m. scutellata colonies produced only male offspring. In the natural hybrid zone 6 out of 14 colonies (43\%) produced only female offspring whereas not a single colony produced only male offspring (Tab. I). In $57 \%$ of the hybrid colonies offspring of both sexes were reared, however, hybrid colonies produced significantly more female offspring than male offspring $(\mathrm{z}=7.82$, $p<0.0001)$. Interestingly, the laying workers laid female eggs in worker cells and male eggs in drone cells.

The ratios of worker to drone cell construction in our test colonies are shown in Table I. The queenless, broodless $A$. $m$. capensis colonies built only worker cells while the A. $m$. scutellata colonies built only drone cells. The results clearly show that workers which are morphometrically and reproductively defined as pure $A$. $m$. capensis had a worker to drone cell ratio of 1:0 and indeed only worker brood was reared in those colonies. Moreover, the pure A. $m$. scutellata colonies produced a worker to drone cell ratio of 0:1 and only male offspring was reared. The ratios of worker to drone cell construction across the hybrid zone are variable (Tab. I). All of the queenless, broodless hybrid colonies produced worker comb cells and $57 \%$ of them also produced drone cells, but in significantly fewer amounts $\left(\chi^{2}=15.08\right.$, df $=2$, $p=0.00053$, Tab. I). The ratios of workers to drones were converted into frequencies and then compared using a chi-square test.

All colonies which had only thelytokous reproducing laying workers built only worker cells, while colonies which produced male and female worker offspring constructed both types of brood cells. This distribution was significantly different from random $\left(\chi^{2}=11.0, \mathrm{df}=1, p=0.0009\right.$, Fisher's exact test $p=0.003$ ).

Interestingly, there is a significant correlation between the number of queen cells constructed per colony and the locality sampled. The more northerly the colonies that were sampled (equals more A. m. scutellata-like region of the hybrid zone), the fewer queen cells were constructed $\left(r=-0.684, \mathrm{n}=26, p=0.001, \mathrm{r}_{\mathrm{s}}=-0.683\right.$, $\mathrm{n}=26, p=0.000122)$. Colonies of pure A. m. capensis constructed significantly more queen cells $\left(\chi^{2}=12.75\right.$, df $=2$, $p=0.0017)$ than the hybrid colonies.

\section{DISCUSSION}

In the methods (see above) it is clear that the colonies had to build their own combs and were also native bees, including the hybrids. The native element is important because this means that the situation observed is likely to be the result of naturally occurring processes of gene flow, migration, etc. between the two races. The colonies were artificially made queenless and broodless. This may have affected the results in that the normal route to being queenless and broodless is via a period in which there is no queen, but in which brood usually occurs (cf. [4]). This may be of relevance to the competition among the racial types in hybrid colonies because non-capensis bees typically attempt to rear a new queen rather than going straight into worker reproduction as in capensis (cf. [4]). Moreover, capensis may have been favoured through a difference in the rate at which ovaries are activated or the proportion with previously activated ovaries (cf. [4]). Thus, the experimental design may have been somewhat stacked in favour of capensis.

Nevertheless, our results show that reproductive dominance in queenless honeybee colonies is strongly affected by the mode of worker reproduction. Although we found a significantly high amount of female offspring among the hybrid colonies, this dominance is not exclusive because within colonies from the natural hybrid zone both worker and drone offspring were simultaneously reared. However, the modes of 
worker reproduction and the construction of brood cells within queenless colonies are clearly co-dependent. In colonies with only thelytokous laying workers exclusively worker cells were constructed, whereas colonies with only arrhenotokous laying workers built only drone cells. Colonies with both arrhenotokous and thelytokous reproducing workers constructed both types of brood cells.

Interestingly, the number of queen cells reared after queen loss seems to be dependent upon population structure. A. m. capensis colonies reared significantly more queen cells than the hybrids and we found a negative correlation within the hybrid zone from the more capensis-like region to the more scutellata-like region. In the lack of any quantitative comparative data on the number of queen cells built in this region, it may be that eggs derived from thelytokous laying worker patrilines occurring in the south may stimulate more queen cell building compared to the north. A role for brood pheromones in modulating the feeding behaviour of workers has been shown [9].

It might well be that thelytokous patrilines, presenting a more $A$. $m$. capensis like genotype, are innately predisposed to become dominant because only offspring of those patrilines can be used for re-queening the orphaned colonies. However, it might also well be that arrhenotokous reproducing patrilines are dominant in the hybrid zone, because high frequencies of thelytoky only occur in A. m. capensis.

That both worker and drone offspring were simultaneously reared in the hybrid colonies confirms previous observations [17] that successful reproduction of arrhenotokous and thelytokous workers in one honeybee colony is possible. Thus, it is obvious that arrhenotokous workers are also able to become reproductively dominant even if thelytokous laying workers are present in the queenless colony. We argue that the proximate reason for thelytokous laying workers being predisposed to become repro- ductively dominant is that thelytoky itself is closely linked with important traits leading to reproductive hierarchies among workers, such as differing pheromonal bouquets and/or differences in ovariole development of the subordinate and dominant workers (cf. [4]). Every test colony within the hybrid zone tried to rear queens from laying worker offspring, supporting the idea that the primary function of thelytoky is to replace lost queens $[10,11]$. This may provide the ultimate reason for the dominance of thelytokous laying workers in the hybrid colonies.

In the test colonies workers constructed brood cells after queen loss according to the mode(s) of worker reproduction of the laying workers present in the colony. Cell construction and reproductive dominance may act synergistically. If no surrogate queen is present in a chain of building workers, drone cells are constructed and arrhenotokous laying workers may develop too because there has not been sufficient time for thelytokous workers to suppress them pheromonally. This may provide a parsimonious explanation for our findings and give support to the importance of decentralised decision making processes in honeybee colonies [18], as well as to the importance of the spatial distributions of workers among their colonies [14].

The thelytokous workers may dispense with building drone comb at all, even though they have a pseudoqueen. This is supported by other observations that $A$. m. capensis workers tend to respond to queenless conditions in a different way from other honeybee workers. For example the inapplicability of queen removal as a stimulus for new queen production (cf. [4]) and the development of laying workers despite the presence of eggs and young larvae $[1,5]$ clearly show that Cape honeybee workers seem to have different behavioural mechanisms after queen loss. Given that the building period was only 30 days, it might well be that the absence of drone comb simply reflects that the workers were starting their combs from scratch, and concentrated on 
worker comb building first. Likewise, the presence of drone comb in the hybrids would reflect the fact that some arrhenotokous workers were not "convinced" by the pseudoqueen, and behaved as though hopelessly queenless.

In conclusion, our data gives strong support to other studies showing that the mode of worker reproduction holds major consequences for other behavioural traits of honeybees $[7,13,14]$.

\section{ACKNOWLEDGEMENTS}

We are grateful to S. Fuchs, R.F.A. Moritz, S. Pratt and an anonymous referee for valuable comments on earlier versions of the manuscript. Financial support was granted by a Rhodes University fellowship to $\mathrm{PN}$.

Résumé - Modes de reproduction des ouvrières, dominance de reproduction et construction des cellules de couvain dans des colonies orphelines d'Apis mellifera $\mathbf{L}$. Le long d'un transect à travers la zone d'hybridation naturelle entre $A$. mellifera capensis, à reproduction thélytoque, et A. mellifera scutellata, à reproduction arrhénotoque, 70 colonies indigènes ont été récoltées (voir tableau pour les lieux). Toutes les reines et tous les rayons ont été ôtés et les abeilles adultes ont été transférées dans des ruches complètement vides. Un fort pourcentage des colonies a essaimé $(n=43)$ et une colonie est morte. Pour les 26 colonies restantes on a calculé le rapport entre les cellules de couvain d'ouvrières et les cellules de couvain de mâles qui avaient été construites et on a déterminé le sexe de la descendance des ouvrières pondeuses. Les ouvrières pondeuses d'A. $m$. capensis n'ont produit qu'une descendance femelle, celles d'A. m. scutellata que des mâles (Tab. I). Dans 42,2 \% des colonies naturellement hybrides on n'a trouvé qu'une descendance femelle et il ne s'est pas trouvé une seule colonie qui ait produit du couvain de mâles
(Tab. I). Ceci montre que les ouvrières pondeuses ont significativement avantage à obtenir une dominance de reproduction dans les colonies hybrides orphelines $(\mathrm{z}=7,82$, $p<0,0001)$. Dans 57,9 \% des colonies hybrides, pourtant, aucune ouvrière ni aucun mâle n'est parvenu jusqu'à l'émergence, ce qui montre que la dominance de reproduction dans les colonies hybrides n'est pas exclusivement déterminée par le mode de reproduction des ouvrières. Les colonies d'A. m. capensis n'ont construit que des cellules d'ouvrières, celles d'A. $m$. scutellata que des cellules de mâles. Les colonies hybrides ont construit soit des cellules de mâles et des cellules d'ouvrières, soit uniquement des cellules d'ouvrières, selon le mode de reproduction des ouvrières qui a pu être mis en évidence dans les colonies. Dans toutes les colonies hybrides où des ouvrières pondeuses ont donné une descendance mâle, on a pu trouvé aussi des cellules de mâles. Cette distribution était significativement différente d'une distribution aléatoire $\left(\chi^{2}=11,0, \mathrm{FG}=1, p=0,0009\right.$, test exact de Fisher $p=0,03)$. Les cellules de couvain de mâles ont été construites en proportion significativement moindre $\left(\chi^{2}=15,8, \mathrm{FG}=2, p=0,00053\right.$, Tab. I). Toutes les colonies avec des ouvrières pondeuses thélytoques ont construit des cellules royales mais le nombre a d'autant plus diminué que les colonies étaient situées plus au nord (dans la direction de la région de $s c u$ tellata $)(\mathrm{r}=0,684, \mathrm{n}=26, p=0,001$, $\left.\mathrm{r}_{\mathrm{s}}=0,683, \mathrm{n}=26, p=0,000122\right)$. Les colonies d'A. m. capensis ont produit significativement plus de cellules royales que les colonies hybrides $\left(\chi^{2}=12,75, \mathrm{FG}=2\right.$, $p=0,0017$, Tab. I). Nos données confirment les résultats d'autres travaux, selon lesquels le mode de reproduction des ouvrières influence d'autres types de comportement des abeilles domestiques.

\section{Apis mellifera capensis / Apis mellifera scutellata / hybride / ouvrière pondeuse / dominance de reproduction}


Zusammenfassung - Modus der Arbeiterinnenreproduktion, reproduktive Dominanz und Brutwabenbau in weisellosen Völkern der Honigbiene (Apis mellifera L.). Entlang eines Transekts durch die natürliche Hybridzone zwischen A. m. capensis mit thelytoker und A. m. scutellata mit arrhenotoker Arbeiterinnenreproduktion wurden 70 native Völker gesammelt (Standorte s. Tab. I). Alle Königinnen und Waben wurden entnommen und die adulten Bienen wurden in neue, komplett leere Beuten überführt. Ein hoher Anteil der Völker schwärmte oder starb $(n=44)$. Für die verbleibenden 26 Völker wurde das Verhältnis der gebauten Arbeiterinnen- und Drohnenbrutzellen und das Geschlecht des Nachwuchses der legenden Arbeiterinnen bestimmt. Legende Arbeiterinnen von A. $m$. capensis produzierten nur weibliche Nachkommen und legende Arbeiterinnen von A. m. scutellata nur Drohnen (Tab. I). In 42,1\% der natürlichen Hybridvölker wurden nur weibliche Nachkommen gefunden und kein einziges Volk produzierte exklusiv Drohnenbrut (Tab. I). Dies zeigt einen signifikanten $(\mathrm{z}=7,82, p<0,0001)$ Vorteil für thelytoke legende Arbeiterinnen, reproduktive Dominanz in weisellosen Hybridvölkern zu erlangen. In 57,9 \% der Hybridvölker wurden jedoch sowohl Arbeiterinnen als auch Drohnen bis zum Schlupf aufgezogen, was darauf hindeuet, dass reproduktive Dominanz in den Hybridvölkern nicht ausschließlich durch den Modus der Arbeiterinnenreproduktion determiniert wird. Die A. m. capensis Völker bauten ausschlie $\beta-$ lich Arbeiterinenzellen, wohingegen in den A. m. scutellata Völkern ausschlie $\beta$ lich Drohnenzellen gefunden wurden. Die Hybridvölker bauten entweder Drohnenund Arbeiterinnenzellen oder nur Arbeiterinnenzellen je nach dem Modus der Arbeiterinnenreproduktion, der in den Völkern nachgewiesen werden konnte. In allen Völkern, in denen legende Arbeiterinnen Drohnenbrut produzierten, konnten auch Drohnenzellen gefunden werden. Dies war signifikant verschieden von einer zufälligen Verteilung $\left(\chi^{2}=11,0, \mathrm{FG}=1\right.$, $p=0,0009$, Fisher's Exakt Test $p=0,003$ ). Drohnenbrutzellen wurden in signifikant geringerem Ausma $\beta$ gebaut $\left(\chi^{2}=15,08\right.$, $\mathrm{FG}=2, p=0,00053$, Tab. I). Alle Völker mit thelytoken legenden Arbeiterinnen bauten Weiselzellen. Die Anzahl der Weiselzellen nahm jedoch signifikant ab, je weiter nördlich (in Richtung der scutellata Region) die Völker gesammelt wurden $(r=-0,684$, $\mathrm{n}=26, p=0,001, \mathrm{r}_{\mathrm{s}}=-0,683, \mathrm{n}=26$, $p=0,000122)$. A. m. capensis Völker produzierten signifikant mehr Weiselzellen als die Hybridvölker $\left(\chi^{2}=12,75, \mathrm{FG}=2\right.$, $p=0,0017$, Tab. I). Unsere Daten unterstützen die Ergebnisse anderer Arbeiten, dass der Modus der Arbeiterinnenreproduktion einen Einflu $\beta$ auf andere Verhaltensweisen von Honigbienen hat.

\section{REFERENCES}

[1] Anderson R.H., The laying worker in the Cape honeybee, Apis mellifera capensis, J. Apic. Res. 2 (1963) 85-92.

[2] Hepburn H.R., Reproductive cycling and hierarchical competition in Cape honeybees, Apis mellifera capensis Esch, Apidologie 25 (1994) 38-48.

[3] Hepburn H.R., Crewe R.M., Portrait of the Cape honeybee, Apis mellifera capensis, Apidologie 22 (1991) 567-580.

[4] Hepburn H.R., Radloff S.E., Honeybees of Africa, Springer Verlag, Berlin, 1998.

[5] Hepburn H.R., Nefdt R.J.C., Whiffler L.A., Queen loss in the Cape honeybee: the interactions of brood, laying workers (false queens?) and queen cells, South Afr. J. Sci. 80 (1988) 363-368.

[6] Hepburn H.R., Villet M.H., Jones G.E., Carter A.R., Simon U.I., Coetzer W., Winter absconding as a dispersal mechanism of the Cape honeybee, South Afr. J. Sci. 89 (1993) 294-297.

[7] Hepburn H.R., Reece S., Neumann P., Moritz R.F.A., Radloff S.E., Absconding in honeybees (Apis mellifera) in relation to queenstate and mode of worker reproduction, Insectes Soc. 46 (1999) 323-326.

[8] Hillesheim E., Koeniger N., Moritz R.F.A. Colony performance in honeybees (Apis mellifera capensis Esch.) depends on the proportion of subordinate and dominant workers, Behav. Ecol. Sociobiol. 24 (1989) 291-296. 
[9] Le Conte Y., Streng L., Poitout S.H., Brood pheromone can modulate the feeding behaviour of Apis mellifera workers (Hymenoptera: Apidae), J. Econ. Entomol. 88 (1995) 798-804.

[10] Lenoir A., Cagniant H., Role of worker thelytoky in colonies of the ant Cataglyphis cursor (Hymenoptera: Formicidae), Entomol. Gen. 11 (1986) 153-157.

[11] Moritz R.F.A., Two parthenogenetical strategies of laying workers in populations of the honeybee Apis mellifera (Hymenoptera, Apidae), Entomol. Gen. 11 (1986) 159-164.

[12] Moritz R.F.A., Kryger P., Allsopp M.H., Competition for royalty in bees, Nature 384 (1996) 31.

[13] Moritz R.F.A., Kryger P., Allsopp M.H., Lack of worker policing in the Cape honeybee (Apis mellifera capensis), Behaviour 136 (2000) 1079-1092.
[14] Moritz R.F.A., Crewe R.M., Hepburn H.R., Clustering of related workers in the honeybee colony (Apis mellifera L.), Apidologie 31 (2000) 223-233.

[15] Neumann P., Moritz R.F.A., van Praagh J., Queen mating frequency in different types of honeybee mating apiaries, J. Apic. Res. 38 (1999) 11-18.

[16] Neumann P., Moritz R.F.A., Mautz D., Colony evaluation is not affected by the drifting of drone and worker honeybees (Apis mellifera L.) at a performance testing apiary, Apidologie 31 (2000) 67-79.

[17] Pettey F.W., Worker laying in comb of extracting supers, J. Dept. Agric. Union South Afr. 4 (1922) 122-124.

[18] Pratt S.C., Decentralised control of drone comb construction in honey bee colonies, Behav. Ecol. Sociobiol. 42 (1998) 192-205. 